15. Hu, J. Y., Li, S. L., Lin, F., Peng, F. H., Yang, S. and Yu, Z. F., Research on disaster monitoring of overburden ground pressure and surface subsidence in extra-large mined-out area. Rock Soil Mech., 2014, 4, 1117-1122.

16. Wang, Y. M., Lu, Y. G. and Sun, G. Q., Study on the law of rock movement and surface subsidence by deep mining with sublevel caving. Met. Mine., 2015, 6, 6-9.

17. Zheng, H. C., Song, C. Y., Hu, L., Xiao, G., Li, M. and Zhang, X. J., Simulation of air shock waves induced by large-scale roof caving in huge mined out area. J. Univ. Sci. Technol. Beijing, 2010, 3, 277-281+3.

18. Carter, T. G., Guidelines for use of the scaled span method for surface crown pillar stability assessment. In Proceedings of 1 st International Conference on Applied Empirical Design Methods in Mining, Lima-Perú, 9-11 June 2014, pp. 1-34.

19. Zhang, M. S., Zhu, W. C., Hou, Z. S. and Guo, X. Q., Numerical simulation for determining the safe roof thickness and Critical Goaf Span. J. Min. Saf. Eng., 2012, 4, 543-548.

20. Garrard, G. F. G. and Taylor, R. K., Collapse mechanisms of shallow coal-mine workings from field measurements. Geol. Soc. Eng. Geol. Spec. Publ., 1988, 25, 181-192.

21. Kratzsch, H., Mining Subsidence Engineering, Springer-Verlag, Berlin, Heidelberg, New York, 1983, pp. 58-59.

22. Sainsbury, B., Pierce, M. and Mas Ivars, D., Analysis of caving behaviour using a synthetic rock mass-ubiquitous joint rock mass modelling technique. In Proceedings of the 1st Southern Hemisphere International Rock Mechanics Symposium (SHIRMS), 2008, pp. 243-253.

23. Terzaghi, K., Theoretical Soil Mechanics, John Wiley and Sons, New York, 1943.

24. Duplancic, P., Characterization of caving mechanisms through analysis of stress and seismicity. Unpublished $\mathrm{Ph} D$ thesis, Department of Civil and Resource Engineering, University of Western Australia, 2002, p. 227.

25. Cai., M., Kaiser, P. K. and Uno, H., Estimation of rock mass deformation modulus and strength of jointed hard rock masses using the GSI system. Int. J. Rock Mech. Min. Sci., 2004, 41(1), 3-19.

26. $\mathrm{Hu}, \mathrm{S} . \mathrm{M}$. and $\mathrm{Hu}, \mathrm{X} . \mathrm{W}$., Estimation of rock mass parameters based on quantitative GSI system and Hoek-Brown criterion. Rock Soil Mech., 2011, 32, 861-866.

27. Hoek, E., Carter, T. G. and Diederichs, M. S., Quantification of the geological strength index chart. In 47th US Rock Mechanics/Geomechanics symposium, San Francisco, USA, 23-26 June 2013, p. 8.

28. Hoek, E., Carranza-Torres, C. T. and Corkum, B., Hoek-brown failure Crition, 2002 Edition, Ion Proceedings of Narms-tac Conference, Toronto, 2002, 1, 267-273.

ACKNOWLEDGEMENT. The authors wish to acknowledge the contributions of Prof. S. K. Satheesh in reviewing a draft of this paper and in participating in the development of crown pillar caving of the minedout area.

Received 16 August 2018; revised accepted 10 October 2018

doi: $10.18520 / \mathrm{cs} / \mathrm{v} 116 / \mathrm{i} 4 / 654-660$

\section{Estimation of regional groundwater discharge and baseflow contribution in northern stretch of the Yamuna River system of Delhi}

\author{
Aryaman Jain ${ }^{1, *}$ and Shashank Shekhar ${ }^{2}$ \\ ${ }^{1}$ Delhi Technological University, Delhi 110 042, India \\ ${ }^{2}$ Department of Geology, University of Delhi, Delhi 110 007, India
}

Urban agglomerations in India of late have started facing drinking and domestic water scarcity. The city state of Delhi has witnessed accelerated urbanization and an exponential growth in population. In this context, it is desired to locate sustainable groundwater resources in Delhi. This communication examines the northern stretch of the Yamuna floodplain system in Delhi with respect to source sustainability. An aquifer can sustain extensive exploitation only if it is replenished regularly. Though the river floodplain system gets recharged by monsoon flooding, the recharged water may not sustain the source aquifer until the end of summer. Thus before exploitation all floodplains have to be examined vis-à-vis regional groundwater dynamics. In this context it was found that the floodplain system in the northern stretch of River Yamuna receives considerable regional groundwater flow. Some of this also contributes to river flow. The present study has estimated regional groundwater flow in this aquifer stretch of the Yamuna river system as $10,513,460 \mathrm{~m}^{3} / \mathrm{yr}(\sim 11 \mathrm{MCM} / \mathrm{yr})$. Besides, the yearly baseflow contribution to the Yamuna in the study area has been estimated as $518,472 \mathrm{~m}^{3} / \mathrm{yr}$ ( $0.5 \mathrm{MCM} / \mathrm{yr})$.

Keywords: Baseflow, flownets, floodplain, regional groundwater discharge, river system.

THE city state of Delhi has witnessed overexploitation of groundwater resources and fast depletion in groundwater reserves in majority of the aquifer systems ${ }^{1-3}$. The Yamuna, a perennial river, flows from north to south through Delhi (Figure 1).

The Yamuna floodplain in Delhi consists of a layer of younger (or newer) alluvium over an older alluvium ${ }^{2-4}$. The thickness of the younger alluvium layer varies from $70 \mathrm{~m}$ in North Delhi to $30 \mathrm{~m}$ in South Delhi ${ }^{4}$. The younger alluvium is an unconfined aquifer ${ }^{5-8}$. The specific yield of this aquifer had been estimated as 0.2 (refs $4,6,8,9)$.

In the present study, groundwater flow to the Yamuna floodplain was estimated using a flownet construction. In such analysis of groundwater flow, water table contours represent equipotential lines and flow lines indicating the direction of groundwater flow are perpendicular to these

*For correspondence. (e-mail: shashankshekhar01@gmail.com; aryamanjain.aj@gmail.com) 


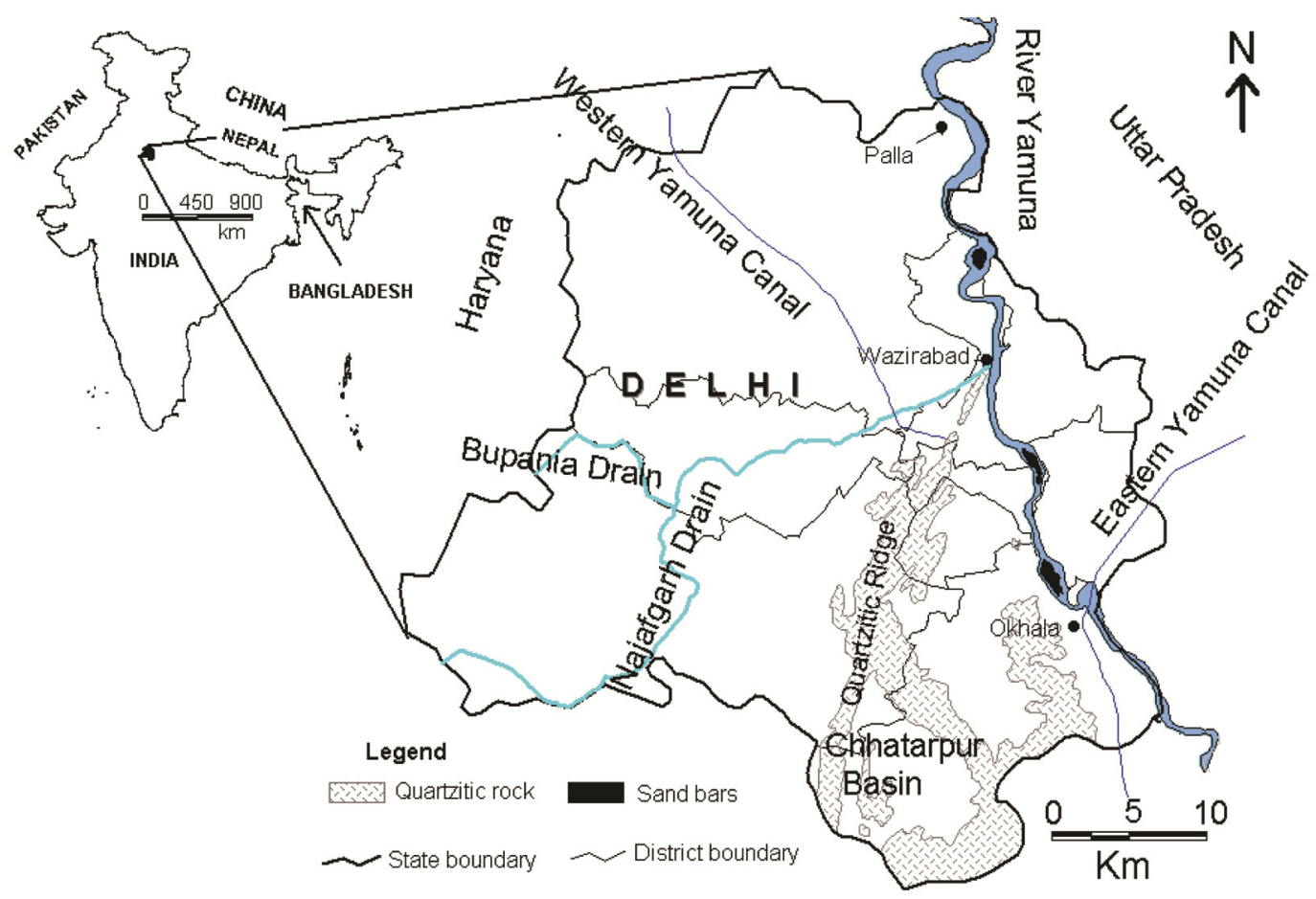

Figure 1. Map showing location of Palla area and River Yamuna in Delhi ${ }^{4}$.

contours (Figure 2). The groundwater flow through the aquifer between two flow lines (Figure 2) is estimated using Darcy's law.

For the water table contours, we used the depth to water table data for January 2013 of the Central Groundwater Board (CGWB) from monitoring stations (Table 1). These data are available in the public domain in the yearbook reports for Delhi and Uttar Pradesh (cgwb.gov.in). Further, the land surface elevation data for these stations were taken from Google Earth imagery. The depth to water table data for a station was subtracted from the land surface elevation data to obtain the water table elevation value for that station (Table 1). With these water table elevation values (Table 1), using Kriging interpolation, water table contour map was prepared (Figure 2). On this map, the flow lines were made perpendicular to the water table contours to construct the flownet (Figure 2). We estimated the groundwater flow through unit saturated thickness of the aquifer along a channel between two flow lines using eq. (1) as follows

$$
Q=k \times\left(\frac{h_{1}-h_{2}}{l}\right) \times w
$$

where $Q$ is the groundwater flow through unit saturated thickness of one channel between two flow lines; $k$ the hydraulic conductivity of the medium, taken to be $20 \mathrm{~m} /$ day for newer alluvium ${ }^{3,6} ; h_{1}$ and $h_{2}$ are the groundwater elevations along length $l$ and $w$ is the width of the flow channel.
In eq. (1), $i$ the hydraulic gradient is represented as

$$
\frac{h_{1}-h_{2}}{l} \text {. }
$$

Figure 2 reveals that there are many channels between flow lines through which groundwater flow takes place towards the Yamuna. So if we consider the $j$ th channel, then the flow $Q_{j}$ through unit saturated thickness of the such $j$ th channel based on eq. (1) can be estimated using eq. (2)

$$
Q_{j}=k i w
$$

The total flow through unit saturated thickness of all the channels which gives an estimate of the regional groundwater flow through unit saturated thickness is calculated using eq. (3)

$$
Q_{\text {total }}=\sum_{j=1}^{n} Q_{j},
$$

where $n$ is the total number of flow channels.

The estimated $Q_{\text {total }}$ in eq. (3) can be multiplied by any aquifer thickness value to give the groundwater flow through that aquifer. So with data taken from Figure 2, we estimated regional groundwater flow per unit saturated thickness to the Yamuna floodplain system from both east and west banks of the river (Table 2). Using this 


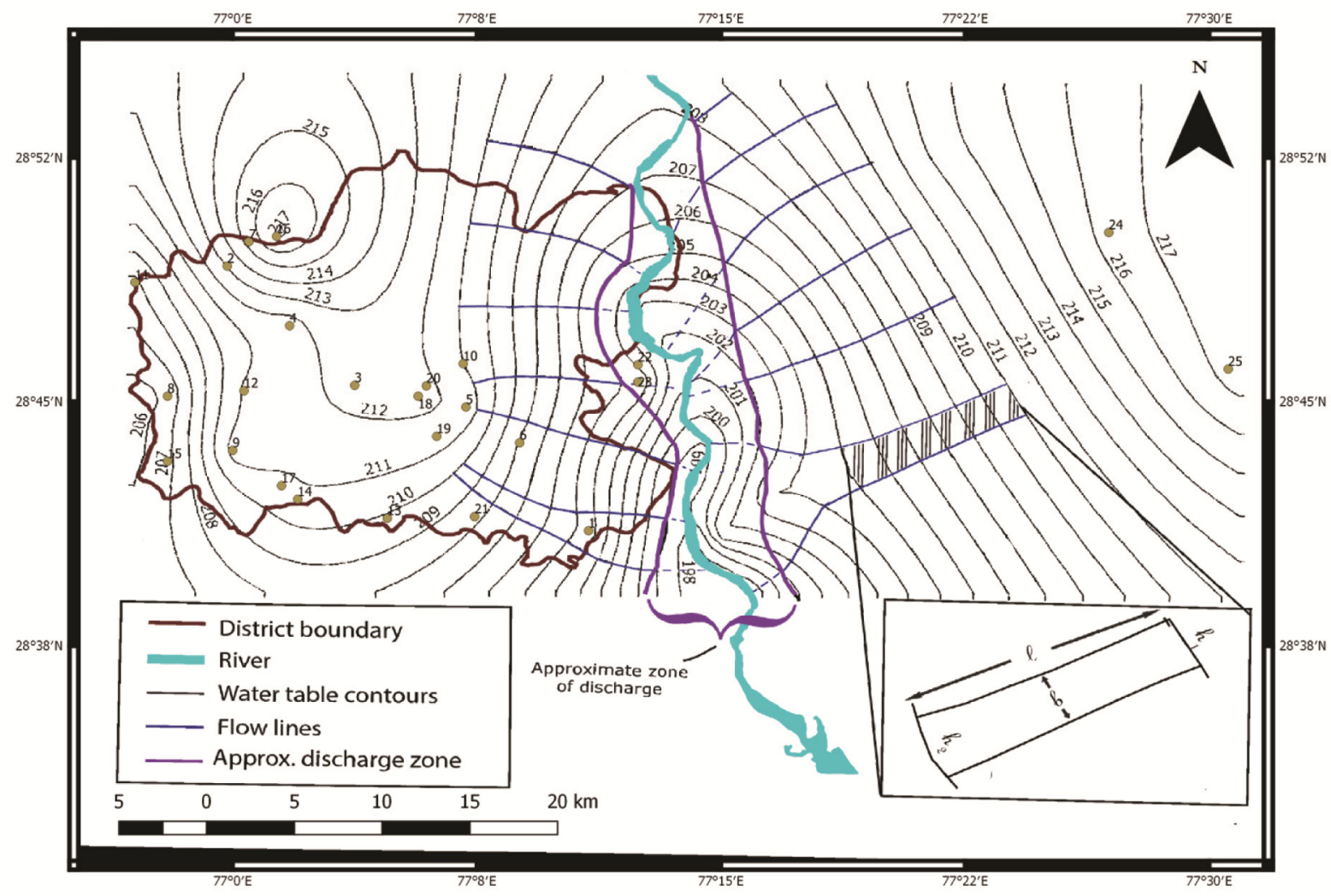

Figure 2. Flow net for estimation of groundwater flow. District shown is North West Delhi. The monitoring stations are shown as circular dots. The numbers besides these are the serial numbers of the respective locations shown in Table 1 .

we estimated the baseflow contribution to the Yamuna, and regional groundwater flow into the flood plain system of the river from an aquifer of $40 \mathrm{~m}$ thickness.

In order to estimate the baseflow contribution to the Yamuna, the average saturated aquifer thickness exposed to the river is required. The channel cross-sections could be roughly estimated from Google Earth, but the problem was with the river stage. So we referred to data from Soni et $a l .{ }^{10}$ on river cross-section, stage and average water surface slope (0.00041) for the Yamuna near Palla (Figure 1). The stage for the other sites was extrapolated using water surface slope data. Further, with the help of Google Earth cross-section, the average saturated aquifer thickness exposed to the river in the study area was estimated as $3 \mathrm{~m}$. So the baseflow contribution to the Yamuna is basically the regional groundwater flow through $3 \mathrm{~m}$ of saturated aquifer. Thus $Q_{\text {total }}$ of eq. (3) was multiplied by 3 for both the east and west banks to estimate baseflow contribution to the river (Table 2). Similarly, for estimation of regional groundwater flow to the Yamuna floodplain system, aquifer of $40 \mathrm{~m}$ thickness was chosen; $Q_{\text {total }}$ of eq. (3) was multiplied by 40 for both the east and west banks (Table 2).

There is a confluence of regional groundwater flow in this stretch of the Yamuna (Figure 2). On summing up the estimates for both banks of the river, our analysis shows that the non-monsoon baseflow to the river is $2160.3 \mathrm{~m}^{3} /$ day. While the total regional groundwater flow to the shallow aquifers of the Yamuna River system is $28,804 \mathrm{~m}^{3} /$ day or $10,513,460 \mathrm{~m}^{3} / \mathrm{yr}$ (Table 2 ).

The natural discharge area of a groundwater system receives regional groundwater flow ${ }^{11}$. Thus floodplain areas close to the river receiving regional groundwater flow corresponding approximately to the area indicating end regime of a regional groundwater flow system were demarcated as discharge zone (Figure 2). The area was found to be roughly $120,263,736 \mathrm{~m}^{2}$. With the estimated $10,513,460 \mathrm{~m}^{3} / \mathrm{yr}$ of groundwater flow into $120,263,736 \mathrm{~m}^{2}$ area, and specific yield ${ }^{4}$ of the aquifer as 0.2 , we estimated the expected rise in groundwater level $(\Delta h)$ without any abstraction and enhancement in baseflow using eq. (4) as follows

$$
\Delta h=\frac{V_{\mathrm{t}}}{A \times S_{\mathrm{y}}},
$$

where $V_{\mathrm{t}}$ is the total annual groundwater discharge, $A$ the discharge area and $S_{\mathrm{y}}$ is the specific yield of the aquifer.

Thus from eq. (4), it is clear that if the total yearly regional groundwater flow volume is not extracted from the region, we should expect a rise in groundwater level of 
RESEARCH COMMUNICATIONS

Table 1. Groundwater-level data

\begin{tabular}{|c|c|c|c|c|c|c|}
\hline Serial no. & Longitude & Latitude & Monitoring station & $\begin{array}{c}\text { Land surface } \\
\text { elevation (m amsl) }\end{array}$ & $\begin{array}{l}\text { Depth to water } \\
\text { table (m bgl) }\end{array}$ & $\begin{array}{c}\text { Water table } \\
\text { elevation (m amsl) }\end{array}$ \\
\hline 1 & 77.18222 & 28.68389 & Ashok Vihar-IV & 216 & 11.4 & 204.6 \\
\hline 2 & 76.99722 & 28.81944 & Auchandi & 224 & 2.3 & 221.7 \\
\hline 3 & 77.0625 & 28.75833 & Barwala & 215 & 5.9 & 209.1 \\
\hline 4 & 77.02917 & 28.78889 & Bawana & 218 & 6.6 & 211.4 \\
\hline 5 & 77.11944 & 28.74722 & Delhi College of Engineering & 217 & 5.2 & 211.8 \\
\hline 7 & 77.00833 & 28.83194 & Hareoli & 220 & 4.6 & 215.4 \\
\hline 8 & 76.96667 & 28.75278 & Jaunti & 219 & 12.9 & 206.1 \\
\hline 9 & 77 & 28.725 & Kanjhawala & 213 & 1.5 & 211.5 \\
\hline 10 & 77.11806 & 28.76944 & Khera Kalan & 216 & 5.0 & 211 \\
\hline 11 & 76.95 & 28.81111 & Kutubgarh & 215 & 7.2 & 207.8 \\
\hline 12 & 77.00583 & 28.75556 & Majara Dabas & 215 & 3.9 & 211.1 \\
\hline 13 & 77.07917 & 28.69028 & Mangolpuri & 219 & 3 & 216 \\
\hline 16 & 77.0225 & 28.83472 & Qatlupur & 219 & 1.7 & 217.3 \\
\hline 17 & 77.025 & 28.70694 & Rani Khera & 214 & 3.5 & 210.5 \\
\hline 18 & 77.095 & 28.75278 & Rohini Sec-28 & 214 & 4.8 & 209.2 \\
\hline 19 & 77.10444 & 28.73222 & Rohini Sec-11 & 218 & 6.5 & 211.5 \\
\hline 20 & 77.09917 & 28.75806 & Rohini Sec-26 & 214.7 & 2.6 & 212.1 \\
\hline 21 & 77.12389 & 28.69111 & Sainik Vihar & 218 & 1.8 & 216.2 \\
\hline 22 & 77.2075 & 28.76889 & Burari Auger & 210.7 & 3.6 & 207.1 \\
\hline 23 & 77.2075 & 28.76 & Burari & 208.7 & 3.8 & 204.9 \\
\hline 24 & 77.44861 & 28.83667 & Raoli & 221 & $9 *$ & $212 *$ \\
\hline 25 & 77.50972 & 28.76667 & Muradnagar & 215.7 & 2.8 & 212.9 \\
\hline
\end{tabular}

*These data were not available and so were interpolated by us. The groundwater level was observed to be approximately $1 \mathrm{~m}$ below Muradnagar's for almost all other data points available, and the same trend was followed in this case also.

Table 2. Regional groundwater discharge and baseflow estimates

\begin{tabular}{|c|c|c|c|}
\hline $\begin{array}{l}\text { Location/ } \\
\text { total estimates }\end{array}$ & $\begin{array}{l}\text { Regional groundwater flow to the } \\
\text { Yamuna floodplain system } \\
\text { per unit saturated thickness }\end{array}$ & $\begin{array}{l}\text { Baseflow contribution to the } \\
\text { Yamuna assuming } 3 \mathrm{~m} \text { of } \\
\text { saturated aquifer exposed to the river }\end{array}$ & $\begin{array}{l}\text { Regional groundwater flow } \\
\text { to shallow aquifer } \\
\text { of } 40 \mathrm{~m} \text { thickness }\end{array}$ \\
\hline West Bank & $443.8 \mathrm{~m}^{3} /$ day & $1331.4 \mathrm{~m}^{3} /$ day & $17,752 \mathrm{~m}^{3} /$ day \\
\hline East Bank & $276.3 \mathrm{~m}^{3} /$ day & $828.9 \mathrm{~m}^{3} /$ day & $11,052 \mathrm{~m}^{3} /$ day \\
\hline Total daily flow & $720.1 \mathrm{~m}^{3} /$ day & $2160.3 \mathrm{~m}^{3} /$ day & $28,804 \mathrm{~m}^{3} /$ day \\
\hline Total yearly flow & $262,836.5 \mathrm{~m}^{3} / \mathrm{yr}$ & $518,472 \mathrm{~m}^{3} / \mathrm{yr}^{*}$ & $10,513,460 \mathrm{~m}^{3} / \mathrm{yr}$ \\
\hline
\end{tabular}

*This was calculated for eight non-monsoon months because it is the period when groundwater contributes to the river. During monsoon months, groundwater will not contribute to the river.

about $0.44 \mathrm{~m} / \mathrm{yr}$. With the average depth to water level being $5 \mathrm{~m} \mathrm{bgl}$, in five years the area would be waterlogged, and soil and groundwater would become saline. Rise in groundwater level will also enhance the baseflow contribution. So we examined the current statistics, where baseflow contribution is only about $8 \%$ of the regional groundwater, flowing into the floodplains; thus the baseflow contribution may increase and the expected rise in groundwater level may reduce to $0.4 \mathrm{~m}$ instead of $0.44 \mathrm{~m}$. However, the possibility of waterlogging will exist if no groundwater is extracted from the floodplains; it may take seven instead of five years.

The estimate arrived at in this study is a ballpark figure. Despite this, the findings on groundwater availability may be significant for Delhi. A more detailed and extensive study would throw further light on how this water resource can be sustainably exploited. However, the regional groundwater dynamics clearly establishes the Yamuna floodplain system in the northern stretch of Delhi as a regional natural groundwater discharge zone, where the regional groundwater flow accumulates. Quantification of regional groundwater flow into the Yamuna floodplain system establishes: that (i) annual regional groundwater flow into the floodplain system works out to be $10,513,460 \mathrm{~m}^{3} /$ day, and (ii) annual baseflow contribution to the Yamuna works out to be $518,472 \mathrm{~m}^{3} / \mathrm{yr}$. With the given estimate of available water for exploitation, it is desirable to optimally exploit groundwater in the 
floodplain system of the study area. While this partially meets water requirement for a part of North Delhi, it will avoid waterlogging.

1. Shekhar, S., An approximate projection of availability of the fresh groundwater resources in the South West district of NCT Delhi, India: a case study. Hydrogeol. J., 2006, 14(7), 1330-1338.

2. Chatterjee, R., Gupta, B. K., Mohiddin, S. K., Singh, P. N., Shekhar, S. and Purohit, R., Dynamic groundwater resources of National Capital Territory, Delhi: assessment, development and management options. Environ. Earth Sci., 2009, 59(3), 669-686.

3. Sarkar, A., Ali, S., Kumar, S., Shekhar, S. and Rao, S. V. N., Groundwater environment in Delhi, India. In Groundwater Environment in Asian Cities: Concepts, Methods and Case Studies, Butterworth-Heinemann, Elsevier, B.V., 2016, pp. 77108.

4. Shekhar, S. and Prasad, R. K., The groundwater in Yamuna flood plain of Delhi (India) and the management options. Hydrogeol. J., 2009, 17, 1557-1560.

5. Shekhar, S., An approach to interpretation of step drawdown tests. Hydrogeol. J., 2006, 14(6), 1018-1027.

6. Rao, S. V. N., Kumar, S., Shekhar, S., Sinha, S. K. and Manju, S., Optimal pumping from skimming wells from the Yamuna River flood plain in north India. Hydrogeol. J., 2007, 15, 1157-1167.

7. Kumar, S., Sarkar, A., Thakur, S. K. and Shekhar, S., Hydrogeological characterization of aquifer in palla flood plain of Delhi using integrated approach. J. Geol. Soc. India, 2017, 90(4), 459-466.

8. Shekhar, S., Mao, R. S. and Imchen, E. B., Groundwater management options in North district of Delhi, India: a groundwater surplus region in over-exploited aquifers. J. Hydrol.: Reg. Stud., 2015, 4, 212-226; http://dx.doi.org/10.1016/j.ejrh.2015.03.003

9. Soni, V., Shekhar, S., Rao, S. V., Kumar, S. and Singh, D., A new solution for city water: quality drinking water from the river floodplains. Curr. Sci., 2018, 114(3), 452-461.

10. Soni, V., Shekhar, S. and Singh, D., Environmental flow for the Yamuna river in Delhi as an example of monsoon rivers in India. Curr. Sci., 2014, 106(4), 558-564.

11. Karanth, K. R., Ground Water Assessment: Development and Management, Tata McGraw-Hill Education, New Delhi, 1987.

Received 20 November 2016; revised accepted 19 November 2018

doi: $10.18520 / \mathrm{cs} / \mathrm{v} 116 / 14 / 660-664$

\section{Modulation in activity profiles in insecticide-resistant population of tobacco caterpillar, Spodoptera litura (Fabricius)}

\author{
P. Sreelakshmi ${ }^{1, *}$, Thomas Biju Mathew ${ }^{1}$, \\ K. Umamaheswaran ${ }^{2}$ and A. Josephrajkumar ${ }^{3}$ \\ ${ }^{1}$ Department of Entomology, and \\ ${ }^{2}$ Department of Plant Pathology, College of Agriculture, Vellayani, \\ Thiruvananthapuram 695 522, India \\ ${ }^{3}$ ICAR-Central Plantation Crops Research Institute, \\ Kayankulam 690 533, India
}

Activity spectrum of detoxification enzymes was systematically assessed in tobacco caterpillar, Spodoptera litura collected from four locations in Kerala, India, to decipher the mechanism of insecticide resistance. Using the susceptible check ICAR-NBAIR strain, specific activity profiles of acetylcholine esterase (AChE) were found to be 16.16-, 10.71- and 4.88-fold higher in the Kovilnada, Palappur and Kanjikuzhi populations respectively. Specific activities of mixed function oxidase (MFO) were also found to be 19.24-, 17.11-, 6.08-fold higher in the same populations respectively, indicating the predominance of $\mathrm{AChE}$ and MFO towards imparting resistance. Carboxylesterase (CarE) and glutathion- $S$-transferase (GST) specific activity profiles were 3.62- and 3.37-fold higher in the Kovilnada population, followed by 2.89 - and 2.98 -fold higher in the Palappur population and as 2.10- and 1.15-fold higher in the Kanjikuzhi population, indicating their partial role in resistance development. Suppression of specific activities in synergism bioassays with $\mathrm{AChE}$ in chlorpyriphos + TPP treatment (9.32-fold), GST in chlorpyriphos + DEM (4.78-fold) and CarE in quinalphos + TPP (5.15-fold) highlighted the involvement of multiple detoxification enzymes conferring resistance to organophosphates. Reduced activity of MFO in case of lambda-cyhalothrin + PBO (5.35-fold), CarE in case of cypermethrin + TPP (7.36-fold) and 3.60-fold reduction in MFO in case of cypermethrin + PBO highlighted the role of esterases and MFOs towards resistance development against synthetic pyrethroids.

Keywords: Detoxification enzymes, insecticide resistance, Spodoptera litura, synergists.

INDISCRIMINATE use of insecticides targeting minor pests has resulted in their development as key pests by rapid gene alterations or physiological mechanisms which have provided these pests the capacity to tolerate toxic doses of insecticides. With the advancement in timeline, the number of insects known to be tolerant to various insecticides has also increased at an alarming rate. In 1986, 260 insect species were reported to have developed

*For correspondence. (e-mail: sreeagri108@gmail.com) 